\title{
The Prevalence of Helicobacter pylori among University Students in Iraq
}

\author{
Bashdar M. Hussen ${ }^{1 *}$, Saleem S. Qader², Halgurd F. Ahmed ${ }^{3}$ and Suha H. Ahmed ${ }^{4}$ \\ 'BSc, MSc, Medical Research Centre, Hawler Medical University, Erbil, Iraq; bashdar@res.hmu.edu.iq \\ ${ }^{2} \mathrm{MBChB}, \mathrm{MD}, \mathrm{MSc}, \mathrm{MPH}, \mathrm{PhD}$, SBGS, Medical Research Centre, Hawler Medical University, Erbil, \\ Iraq; Saleem.Qader@med.lu.se \\ ${ }_{3}^{3} \mathrm{MBCHB}$, FICMS, MRCP1, Trainees Affair, Kurdistan Board for Medical Specialization, Erbil, Iraq; halmaxa@yahoo.com \\ ${ }^{4}$ BSC, MSc, College of Nursing, Hawler Medical University, Erbil, Kurdistan; bmhscience@yahoo.com
}

\begin{abstract}
Background and Objectives: The prevalence of Helicobacter pylori (H. pylori) varies according to the human population and countries. Our objective was to determine the prevalence of $H$. pylori infection among students in Hawler Medical University, Erbil, Iraq.

Methods and Material: 311 students (57.8\% female and 42.2\% male) in four colleges (Medicine, Dentistry, Pharmacy and Nursing) at Howler Medical University were recruited in the study. The diagnosis was based on seroepidimeologic method. H. pylori antigen cassette which is a qualitative immunochromatographic assay contains monoclonal antibodies was used.

Results: Among 311 students 173 (55.8\%) students were infected with H. pylori. H. pylori infection was more common in final year students of each college (61.7\%) comparing with other classes (46.6\%).

Conclusions: H. pylori are highly prevalent among university students in our region. Higher prevalence found in older students and those from low social class.
\end{abstract}

Keywords: H. pylori, Gastritis, Peptic Ulcer, Proton Pub Inhibitor, Gastric Cancer.

\section{Introduction}

Helicobacter pylori are the commonest bacterial infection worldwide. This gram negative bacterium infects human gastric mucosa causing long term colonization and inflammation. It has a helix shape, which thought to have evolved to penetrate the mucoid lining of the stomach [1].

Colonization with $H$. pylori is not a disease by itself but a condition associated with a number of disorders of the upper gastrointestinal tract [2]. It is linked with the development of duodenal ulcers and stomach cancer [3]. However, over 80 percent of individuals infected with this bacterium are asymptomatic [4].

The way of transmission of H. pylori is unclear [5]. Recent studies showed transmission via either faecal-oral or oral-oral route. It may be directly related to the source of drinking water [6]. Infection with $H$. pylori is related to many diseases e.g. iron deficiency anemia, migraine and coronary heart disease [7]. Epidemiological studies demonstrated that $\mathrm{H}$. pylori infection increases with age. It is higher in developing countries and among population with low socioeconomic status. This may be due to poor hygiene, crowded living conditions and absence of sanitation [8].

In developed countries, children and adolescents are only infrequently infected, while in adults over 50 years of age the infection ranges from $30-60 \%$ [8]. In USA, serologic evidence of $H$. pylori is rarely found before age of $10 \mathrm{y}$ but increases to $10 \%$ in those between $18-30 y$ of age and to $50 \%$ in those $>60 y$ [9]. The rate of infection with this bacterium differs in different countries e.g. in Kuwait $81 \%$ [10], in Jordan 82\% [11] and in Turkey 63\% [12].

* Corresponding author:

Bashdar M. Hussen (Bashdar@res.hmu.edu.iq) 
Our objective was to determine the prevalence of $H$. pylori infection among university students.

\section{Methods and Materials}

The study was carried out at Hawler Medical University, including all four colleges (Medicine, Dentistry, Pharmacy and Nursing).

The study has been approved by the Ethics Committee of Medical Research Centre, Hawler Medical University. The students were free to participate in the study or to withdraw at any stage. Students were given complete information about the infection with $\mathrm{H}$. pylori and its consequences. At the end of the study, students infected with $H$. pylori given treatment against the infection.

\subsection{Subjects}

400 students (100 from each college) were included in the study but only 311 students were fulfilled the inclusive criteria. The rest were missing or did not fill the questionnaire or did not agree about the blood test.

\subsection{Blood Collection}

Fresh blood collected by lancet stick from the right thumb of each student under fully aseptic condition. A blood drop was taken from each student and placed on special kit for detection of $H$. Pylori. The test was performed through one step by antigen cassette test (Linear chemicals, S.L, Barcelona, Spain). It is a qualitative immunochromatographic assay using monoclonal antibodies.

\subsection{Questionnaire}

A specially designed questionnaire was used for this study. It assessed participant's health status, social and demographic characteristics. The first part of the questionnaire contained questions regarding the demographic data (age, gender, blood groups and family income). The second part referred to selected features relating to the students' lifestyle such as living conditions, smoking, alcohol, caffeine consumption and the presence of gastric symptoms. The last part of the questionnaire was related to the family history and hygienic behaviors. The questionnaire was filled by the students themselves after short introduction about the study, H. Pylori prevalence and it is effect on our health.

\subsection{Statistics}

Data were analyzed using SPSS (Statistical Package for Social Science, V 20.0) chi-square test to determine the prevalence of $H$. pylori infection in the participants, and the difference in the prevalence across gender and stages. The differences between means were considered significant when $\mathrm{P} \leq 0.05$.

\section{Results}

Our study showed that $H$. pylori was positive in 173 (55.8\%) students, 104 (58.1\%) of them were female and 69 $(52.7 \%)$ were male (Table 1$). H$. pylori infection was higher (67.5\%) among students aged (24-30) years than those students aged $18-20$ year (47.0\%) and those aged $21-23$ year (59.1\%) (Table 2).

226 students living in urban (Erbil) and 57 from rural (living in hostel in Erbil City), and no significant difference found between them (Table 3). Regarding the income level, most of the sero-positive participants $(83.3 \%)$ were from low income social class (P value 0.043 ) (Table 4). Helecobacter positivity and student class, college and blood group were not significant (Table 5,6). In addition, when H. pylori positivity was compared with cola, tea, coffee consumption, drinking water source (natural or minerals) and physical activity (playing sports, lye after meals and daily sleeping) no significant difference was found (Table 7, 8). Decreased appetite was related to Helecobacter positivity (P value 0.027 ) Table 9.

\section{Discussion}

The prevalence of $H$. pylori infection among students in Hawler Medical University was $55.8 \%$, which is lower than in neighboring countries e.g. Kuwait $81 \%$ [10], Jordan $82 \%$

Table 1. Gender and H. pylori

\begin{tabular}{lccll}
\hline \multirow{2}{*}{ Gender } & \multicolumn{2}{c}{ H. pylori test } & Total & $\mathrm{P}^{*}$ \\
\cline { 2 - 3 } & Negative & Positive & & \\
\hline Female & $75(41.9 \%)$ & $104(58.1 \%)$ & 179 & \\
& & & $(57.7 \%)$ & \\
Male & $62(47.3 \%)$ & $69(52.7 \%)$ & 131 & 0.34 \\
& & & $(42.3 \%)$ & \\
Total & $137(44.2 \%)$ & $173(55.8 \%)$ & 310 & \\
& & & $(100 \%)$ & \\
\hline
\end{tabular}


Table 2. H. pylori infection in relation to age

\begin{tabular}{lcccc}
\hline \multirow{2}{*}{$\begin{array}{l}\text { Age of } \\
\text { students }\end{array}$} & \multicolumn{2}{c}{$H$. pylori test } & Total & $\mathrm{P}^{*}$ \\
\cline { 2 - 3 } & Negative & Positive & & \\
\hline $18-20$ & $62(53.0 \%)$ & $55(47.0 \%)$ & $117(37.6 \%)$ & .038 \\
$21-23$ & $63(40.9 \%)$ & $91(59.1 \%)$ & $154(49.5 \%)$ & .037 \\
$24-30$ & $13(32.5 \%)$ & $27(67.5 \%)$ & $40(12.9 \%)$ & .011 \\
Total & $138(44.4 \%)$ & $173(55.6 \%)$ & $311(100 \%)$ & \\
\hline
\end{tabular}

Table 3. H. pylori infection rates in relation to the residency

\begin{tabular}{lcccc}
\hline \multirow{2}{*}{$\begin{array}{l}\text { Residence } \\
\text { of students }\end{array}$} & \multicolumn{2}{c}{ H.pylori test } & \multirow{2}{*}{ Total } & $\mathrm{P}^{*}$ \\
\cline { 2 - 3 } & Negative & Positive & & \\
\hline Urban & $100(44.2 \%)$ & $126(55.8 \%)$ & $226(79.9 \%)$ & 0.958 \\
Rural & $25(43.9 \%)$ & $32(56.1 \%)$ & $57(20.1 \%)$ & \\
Total & $125(44.2 \%)$ & $158(55.8 \%)$ & $283(100 \%)$ & \\
\hline
\end{tabular}

Table 4. H. pylori infection in relation to the income level

\begin{tabular}{lcccc}
\hline \multirow{2}{*}{$\begin{array}{l}\text { Income } \\
\text { level }\end{array}$} & \multicolumn{2}{c}{ H. pylori test } & Total & $\mathrm{P}^{*}$ \\
\cline { 2 - 3 } & Negative & Positive & & \\
\hline Low & $3(16.7 \%)$ & $15(83.3 \%)$ & $18(6.0 \%)$ & 0.043 \\
Good & $122(45.7 \%)$ & $145(54.3 \%)$ & $267(88.4 \%)$ & \\
High & $9(52.9 \%)$ & $8(47.1 \%)$ & $17(5.6 \%)$ & \\
Total & $134(44.4 \%)$ & $168(55.6 \%)$ & $302(100.0 \%)$ & \\
\hline
\end{tabular}

Table 5. H. pylori infection in relation to stage of the study

\begin{tabular}{lcccc}
\hline \multirow{2}{*}{$\begin{array}{l}\text { Class of } \\
\text { student }\end{array}$} & \multicolumn{2}{c}{ H.pylori test } & \multirow{2}{*}{ Total } & $\mathbf{P}^{*}$ \\
\cline { 2 - 3 } & Negative & Positive & & \\
\hline 1st class & $39(53.4 \%)$ & $34(46.6 \%)$ & $73(23.2 \%)$ & 0.211 \\
2nd class & $27(45.8 \%)$ & $32(54.2 \%)$ & $59(18.7 \%)$ & \\
Third class & $32(36.8 \%)$ & $55(63.2 \%)$ & $87(27.6 \%)$ & \\
Forth class & $18(50.0 \%)$ & $18(50.0 \%)$ & $36(11.4 \%)$ & \\
Fifth class & $23(38.3 \%)$ & $37(61.7 \%)$ & $60(19.0 \%)$ & \\
Total & $139(44.1 \%)$ & $176(55.9 \%)$ & $315(100.0 \%)$ & \\
\hline
\end{tabular}

Table 6. H. pylori infection rates in relation to colleges

\begin{tabular}{lcccc}
\hline \multirow{2}{*}{$\begin{array}{l}\text { Name of } \\
\text { the colleges }\end{array}$} & \multicolumn{2}{c}{ H. pylori test } & \multirow{2}{*}{ Total } & $\mathbf{P}^{*}$ \\
\cline { 2 - 4 } & Negative & Positive & & \\
\hline Medicine & $38(40.9 \%)$ & $55(59.1 \%)$ & $93(29.5 \%)$ & 0.361 \\
Dentistry & $43(49.4 \%)$ & $44(50.6 \%)$ & $87(27.6 \%)$ & \\
Pharmacy & $36(48.0 \%)$ & $39(52.0 \%)$ & $75(23.8 \%)$ & \\
Nursing & $22(36.7 \%)$ & $38(63.3 \%)$ & $60(19.0 \%)$ & \\
Total & $139(44.1 \%)$ & $176(55.9 \%)$ & $315(100.0 \%)$ & \\
\hline
\end{tabular}

[11] and Turkey 63\% [12]. This difference may be due to the design of our study in which we screened only medical students and because of their medical background they might have a different life style from the rest of the society. In another word they may take more precautions about their life and try to have healthier life style.

Female students were more infected with $H$. pylori than the male students ( $P$ value: 0.34$)$. This was in contrary to others [13]. It may be due cultural reason that women take care of food preparation more than men and spend more time in the kitchen. Others found no gender-related difference in the prevalence of $H$. pylori infection [14].

Infection with $H$. pylori increased with age (higher rates $67.5 \%$ among students aged $24-30 \mathrm{Y}$ ( $P$ value: 0.011 ), which is in agreement with others [15-18]. This may be due to more exposure to this infection.

H. pylori is highly prevalent in low income students $(P$ value: 0.043 ) in our country which may be due to more sedentary life and bad quality of food.

Crowded living conditions especially high number of children at home increased the risk $[19,20]$ but our data did not show or support this data.

There was no association between drinking-water and H. pylori infection (P vale: 0.738$)$. This was in contrary to others ${ }^{6}$ especially in places where untreated water was used [21]. This may be due to recent improvements in the water basic systems and services.

There was significant association between appetite and $H$. pylori infection ( $P$ value: 0.027$)$ which is in agreement with others $[22,23]$. H. pylori infection leads to chronic active gastritis in all infected individuals and thereby interferes with the release of gastric hormones, which are involved in the regulation of appetite and food intake. $H$. pylori infection leads to a decrease in circulating ghrelin through a reduction in ghrelin-producing cells in the gastric mucosa and to an increase in gastric leptin. Ghrelin 
Table 7. H. pylori infection rates in relation to drinks

\begin{tabular}{llllll}
\hline \multirow{2}{*}{ Drinks } & & \multicolumn{2}{c}{ H. pylori test } & \multirow{2}{*}{ Total } & \multirow{2}{*}{ P $^{*}$} \\
\cline { 2 - 5 } Cola consumption & & Negative & Positive & & \\
& Yes & $67(41.4 \%)$ & $95(58.6 \%)$ & $162(52.9 \%)$ & 0.363 \\
& No & $67(46.5 \%)$ & $77(53.5 \%)$ & $144(47.1 \%)$ & \\
\cline { 2 - 5 } Tea consumption & Total & $134(43.8 \%)$ & $172(56.2 \%)$ & $306(100.0 \%)$ & \\
& Yes & $120(44.9 \%)$ & $147(55.1 \%)$ & $267(85.9 \%)$ & 0.828 \\
& No & $19(43.2 \%)$ & $25(56.8 \%)$ & $44(14.1 \%)$ & \\
\cline { 2 - 5 } Coffee consumption & Total & $139(44.7 \%)$ & $172(55.3 \%)$ & $311(100.0 \%)$ & \\
& Yes & $59(46.1 \%)$ & $69(53.9 \%)$ & $128(41.7 \%)$ & 0.662 \\
& No & $78(43.6 \%)$ & $101(56.4 \%)$ & $179(58.3 \%)$ & \\
\cline { 2 - 5 } Drinking water source & Total & $137(44.6 \%)$ & $170(55.4 \%)$ & $307(100.0 \%)$ & \\
& Natural & $108(43.2 \%)$ & $142(56.8 \%)$ & $250(82.5 \%)$ & 0.738 \\
& Minerals & $25(49.0 \%)$ & $26(51.0 \%)$ & $51(16.8 \%)$ & \\
Total & both & $1(50.0 \%)$ & $1(50.0 \%)$ & $2(0.7 \%)$ & \\
\hline
\end{tabular}

Table 8. H. pylori infection rates in relation to physical activity

\begin{tabular}{|c|c|c|c|c|c|}
\hline \multirow{2}{*}{ Drinks } & & \multicolumn{2}{|c|}{ H. pylori test } & \multirow{2}{*}{ Total } & \multirow{2}{*}{$\mathrm{P}^{*}$} \\
\hline & & Negative & Positive & & \\
\hline \multirow{3}{*}{$\begin{array}{l}\text { playing } \\
\text { sports }\end{array}$} & No & $71(40.6 \%)$ & $104(59.4 \%)$ & $175(57.8 \%)$ & \\
\hline & Yes & $62(48.4 \%)$ & $66(51.6 \%)$ & $128(42.2 \%)$ & .173 \\
\hline & Total & $133(43.9 \%)$ & $170(56.1 \%)$ & $303(100.0 \%)$ & \\
\hline \multirow{3}{*}{$\begin{array}{l}\text { lye after } \\
\text { meals }\end{array}$} & No & $48(48.5 \%)$ & $51(51.5 \%)$ & $99(33.6 \%)$ & \\
\hline & Yes & $81(41.3 \%)$ & $115(58.7 \%)$ & $196(66.4 \%)$ & .242 \\
\hline & Total & $129(43.7 \%)$ & $166(56.3 \%)$ & $295(100.0 \%)$ & \\
\hline \multirow{3}{*}{$\begin{array}{l}\text { Daily } \\
\text { sleeping }\end{array}$} & No & $29(47.5 \%)$ & $32(52.5 \%)$ & $61(20.3 \%)$ & \\
\hline & Yes & $101(42.1 \%)$ & $139(57.9 \%)$ & 240 (79.7\%) & .442 \\
\hline & Total & $130(43.2 \%)$ & $171(56.8 \%)$ & 301 (100.0\%) & \\
\hline
\end{tabular}

Table 9. H. pylori infection rates in relation to appetite

\begin{tabular}{lllll}
\hline \multirow{2}{*}{$\begin{array}{l}\text { Lack of } \\
\text { appetite }\end{array}$} & \multicolumn{2}{c}{ H. pylori test } & \multicolumn{1}{c}{ Total } & $\mathrm{P}^{*}$ \\
\cline { 2 - 3 } & Negative & \multicolumn{1}{c}{ Positive } & & \\
\hline Yes & $21(31.8 \%)$ & $45(68.2 \%)$ & $66(21.6 \%)$ & \\
No & $113(47.1 \%)$ & $127(52.9 \%)$ & $240(78.4 \%)$ & .027 \\
Total & $134(43.8 \%)$ & $172(56.2 \%)$ & $306(100.0 \%)$ & \\
\hline
\end{tabular}

is an important factor in appetite and satiety regul-ation and after successful eradication of $H$. pylori, the number of ghrelin-positive cells in the gastric mucosa turns to normal.

\section{Conclusion}

H. pylori are highly prevalent among university students in our region. The seroprevalence of $H$. pylori is increasing with age. Higher frequency found in students from low income social status.

\section{Acknowledgements}

This study was sponsored by Hawler Medical University. Thanks to the Deans of the colleges (Medicine, Dentistry, Pharmacy and Nursing) for their cooperation. Thanks for the participants. Thanks to Mr. Rebwar J., Mr. Abdulla A., Mrs Ashti M. Said and Mrs. Chiman Hamid for their cooperation.

\section{References}

1. Brown L M, Thomas T L et al. (2002). Helicobacter pylori infection in rural China, International Journal of Epidemiology, vol 31(3), 638-645. 
2. Kusters J. van Vliet A. Kuipers E J. (2006). Pathogenesis of Helicobacter pylori Infection, Clinical Microbiology Reviews, vol 19 (3), 449-490.

3. Lambert J R, Lin S K et al. (1995). Helicobacter pylori, Scandinavian Journal of Gastroenterology - Supplement, vol $30,33-46$.

4. Blaser $J$ (2006). Who are we? Indigenous microbes and the ecology of human diseases, EMBO Reports, vol 7(10), 956-960.

5. Shao K, John R et al. (1998). Ian H J. Helicobacter pylor, Australian Dental J, vol 43(1), 35-39

6. Klein P D, Gilman R et al. (1991). Water source as risk factor for Helicobacter pylori infection in Peruvian children, Lancet, vol 337(8756), 1503-1506.

7. Brown L M (2000). Helicobacter pylori: epidemiology and routes of transmission, Epidemiologic Reviews, vol 22(2), 283-297.

8. Megraud F. Brassens-Rabbe M. Denis F. et al (1989). Seroepidemiology of Campylobacter pylori infection in various populations, Journal of Clinical Microbiology, vol 27(8), 1870-1873.

9. Williams M, and Pounder R (1999). Helicobacter pylori: from the benign to the malignant, The American Journal of Gastroenterology, vol 94(11 suppl), 11-16.

10. Ibrahim B, Anim J et al. (1995). Helicobacter pylori associated chronic gastritis in Kuwait, Annals of Saudi Medicine, vol 15(6), 570-574.

11. Shennak M M, and Kilani A F (1998). Helicobacter pylori in dyspeptic Jordanian patients, Tropical Gastroenterology, vol 19(1), 15-18.

12. Tayfun Y, Dilek A et al. (2008). Prevalence of Helicobacter pylori and related factors in Turkey, Japanese journal of infectious diseases, vol 61(4), 179-183.

13. Jahan H, Chowdhury A, et al. (2010). Helicobacter pylori infection on medical students: A study on MAG Osmani Medical College, Bangladesh, International Journal of Medicine and Medical Sciences, vol 2(11), 354-358.
14. Fraser A, Scragg R et al. (1996). Prevalence of Helicobacter pylori infection in different ethnic groups in New Zealand children and adults, Australian \& New Zealand Journal of Medicine, vol 26(5), 646-651.

15. David Y, Graham Hoda M et al (1991). Epidemiology of Helicobacter Pylori in an Asymptomatic Population in the United States, Gastroenterology, vol 100(6), 1495-501.

16. Tkachenko M, Zhannat $\mathrm{N}$ et al. (2007). Dramatic changes in the prevalence of Helicobacter pylori infection during childhood, J Pediatr Gastroenterol Nutr, vol 45(4), 428-432.

17. Parsonnet J (1995). The incidence of Helicobacter pylori infection, Alimentary Pharmacology \& Therapeutics, vol 9(Suppl 2), 45-51.

18. Fujisawa T, Kumagai T et al. (1999). Changes in seroepidemiological pattern of Helicobacter pylori and hepatitis A virus over the last 20 years in Japan, The American Journal of Gastroenterology, vol 94(8), 2094-2099.

19. Breuer T, Sudhop T et al. (1996). Prevalence and risk factors for Helicobacter pylori infection in the western part of Germany, European Journal of Gastroenterology \& Hepatology, vol 8(1), 47-52.

20. Goodman K J, and Correa P (1995). The transmission of Helicobacter pylori, a critical review of the evidence, International Journal of Epidemiology, vol 24(5), 875-887.

21. Nugalieva Z, Malaty $H$ et al. (2002). Helicobacter pylori infections in Kazakhstan: effect of water source and household hygiene, The American Journal of Tropical Medicine and Hygiene, vol 67(2), 201-206.

22. Weigt J, and Malfertheiner P (2009). Influence of Helicobacter pylori on gastric regulation of food intake, Current Opinion in Clinical Nutrition \& Metabolic Care, vol 12(5), 522-525.

23. Tatsuguchi A, Miyake K et al. (2004). Effect of Helicobacter pylori infection on ghrelin expression in human gastric mucosa, The American Journal of Gastroenterology, vol 99(11), 2121-2127. 